\title{
Consensus
}

Volume 28

Issue 2 Spirituality and Health

Article 25

$11-25-2002$

\section{Thomas Merton and the Monastic Vision}

Kevin Powell

Follow this and additional works at: http://scholars.wlu.ca/consensus

\section{Recommended Citation}

Powell, Kevin (2002) "Thomas Merton and the Monastic Vision," Consensus: Vol. 28 : Iss. 2 , Article 25.

Available at: http://scholars.wlu.ca/consensus/vol28/iss $2 / 25$

This Book Reviews is brought to you for free and open access by Scholars Commons @ Laurier. It has been accepted for inclusion in Consensus by an authorized editor of Scholars Commons@ Laurier. For more information, please contact scholarscommons@wlu.ca. 
Certainly, the work by Wesley Carr, the associate editors and the many contributors in putting together The Dictionary of Pastoral Studies is a Herculean task. As he admits in the Introduction, there is no perfect dictionary. I disagreed with some presentations and lamented that others were missing. However, I give it an eight out of ten. It will certainly occupy an important place on my shelf.

Thomas St. James O' Connor, ThD

Assistant Professor, Pastoral Care and Counselling

Waterloo Lutheran Seminary

\section{Thomas Merton and the Monastic Vision}

Lawrence S. Cunningham

Grand Rapids, MI: Eerdmans, 1999

228 pages, $\$ 24.95$ Softcover

Given the overabundance of "mertonia" that has emerged since his death in 1968, sorting through the many books, articles, videos, tapes, monographs, etc, to obtain an accurate rendering and thoughtful analysis of Thomas Merton's life can be a daunting task indeed. Lawrence Cunningham has written a brief but thorough study of Merton's life and thought that offers an excellent introduction to his writings and influence in twentieth century religious life.

Cunningham places Merton in the context of both the early monastic Fathers and Mothers, whose influence played an important role in his development as a monk, and the vast changes of the Second Vatican Council amidst the social and political upheavals of the 1960's. As committed as Merton was to peace issues and the civil rights movement, his involvement grew out of a profound engagement with monastic tradition and his life as a contemplative monk. This brings me to Cunningham's thesis:

...the prolific works which flowed from Merton's pen and the impact that those writings and his person had and continue to have can only be understood against the background of his contemplative experience as a 
Trappist monk. Indeed...one cannot understand Thomas Merton if one does not understand him as a monk (17).

Cunningham's treatment steers clear of hagiography. He paints a portrait of Merton that intermingles his less than holy moments, i.e., his pettiness towards his Abbot (James Fox) when he was refused travel, his (understandable, if not childish) tirades against the American Catholic hierarchy, his affair with " $\mathrm{M}$ ", the nurse with whom Merton fell in love, with a profound engagement with his active mind and his contemplative vocation. Just as Merton himself did not cover up his "failings" in the journals he knew would be published, Cunningham reveals parts of Merton's personality that were less than glamorous or saintly.

However, the great strength of this book is how the author brings together the various and complex pieces that make up the life and work of Thomas Merton and creates not a "plaster statue" of Merton the saint (although there is a movement of admirers who are advocating his canonization, Merton would be aghast at the thought!), but an engaging portrayal of a person of profound faith struggling to understand the significance of his life in the midst of an unbelieving world and a church deeply invested in American culture.

Contemplation, for Merton, was not to be confused with "recharging your spiritual batteries", but was a way of life that under girded action. Merton's relevance to the modern reader lies in his constant struggle to understand the role of the contemplative (or the Christian) in postChristian society, his search for an authentic expression of faith, and his prophetic condemnations of unchecked capitalism and the culture of violence it creates. His words in the 1960's can be read with the same relevance as when they were written. Cunningham offers a tremendously readable account of Merton's life and work that provides a clean segue into the writings of Merton himself. In fact, the final chapter is a bibliographic essay that will help the reader discern with which "Merton" (i.e., Merton the social critic, the poet, the theologian, the teacher, etc) one might like to begin. But whichever "Merton" one reads, one will always be reading "Merton the monk."

Kevin Powell

Lutheran Church of the Resurrection

Halifax, Nova Scotia 